\title{
Adsorbed protein detection by scanning electrochemical microscopy
}

\author{
Fernando Cortés-Salazar, Jean-Marc Busnel, Fei Li, Hubert H. Girault* \\ Laboratoire d'Electrochimie Physique et Analytique, Ecole Polytechnique Fédérale de Lausanne, Station 6, CH-1015 Lausanne, Switzerland
}

\section{A R T I C L E I N F O}

\section{Article history:}

Received 22 May 2009

Received in revised form 29 July 2009

Accepted 4 August 2009

Available online 13 August 2009

\section{Keywords:}

Scanning electrochemical microscopy

Protein detection

Protein tagging

Benzoquinone

Fingerprint

Imaging

\begin{abstract}
A B S T R A C T
A scanning electrochemical microscopy (SECM) protein detection methodology has been developed based on the tagging of free cysteines and other nucleophiles in proteins and peptides by benzoquinone. The tagged proteins are detected by the mediated reduction of benzoquinone with a redox species produced electrochemically at the SECM tip. After careful optimization, a sensitivity in the low $\mathrm{ng} \mathrm{mm}^{-2}$ range was reached for bovine serum albumin. One of the major advantages of the present technique is that the selectivity of the protein tagging can be tuned by changing the $\mathrm{pH}$ of the reaction media. Depending on the requirements, cysteine selective or general detection can therefore be achieved with a high sensitivity. As a proof of concept, this technique was applied to the detection of protein spots and to the imaging of human fingerprints and further compared to the actual SECM state-of-art approach.
\end{abstract}

(c) 2009 Elsevier B.V. All rights reserved.

\section{Introduction}

The development of sensitive and selective techniques for protein detection has been extensively pursued since low abundance proteins have been shown to play relevant roles at all the levels of biological processes $[1,2]$. In systems such as yeast, these proteins furthermore represent $80 \%$ of the predicted proteome $[3,4]$. In gels or in human fingerprints, proteins are usually visualized by optical techniques based on protein staining with either metal ions such as silver [5], organic substances [6] or fluorescent dyes [7-9]. Radioactive isotope labels have also been used [10], but despite of the very high sensitivity with reported attomole detection limits, the handling of radioactive materials and their cost makes the routine use of this technique rather cumbersome [9]. From a sensitivity point of view, fluorescence methodologies are also very powerful. Indeed, detection of proteins, after derivatization $[7,8]$ or by native fluorescence [11], has been reported with detection limits close to 5 pg per band on polyacrylamide gels and between 0.25 and $1 \mathrm{ng} \mathrm{mm}^{-2}$ on polyvinylidene fluoride (PVDF) membranes [12]. Still, this approach is somehow costly as expensive fluorescent dyes and/or fluorescence scanners are required [13]. Electrochemical detection of proteins by scanning electrochemical microscopy (SECM) has been developed in conjunction with techniques like immunodetection [14,15] or metal staining [16-19]. Recently, it has been reported that the sensitivity of the silver staining technique can be enhanced to $0.5 \mathrm{ng} \mathrm{mm}^{-2}$ by the use of SECM as a readout tool [19].

\footnotetext{
* Corresponding author. Tel.: +41 21693 3145; fax: +41 216933667.

E-mail address: hubert.girault@epfl.ch (H.H. Girault).
}

SECM is a scanning probe technique suitable for locally detecting electrochemical and/or chemical surface reactivity with a high resolution and sensitivity $[20,21]$. SECM is often used by monitoring the steady state current achieved at a microelectrode, when it is moved in horizontal $(x, y)$ or vertical $(z)$ direction over a scanned surface. Quantitative kinetic information of both heterogeneous and homogeneous reactions can additionally be extracted by fitting the experimental results with numerical simulations based on kinetics and mass transport models [22-24]. The SECM versatility allows electrochemical studies at almost any interface (i.e. liquid/solid, liquid/liquid and gas/solid interfaces) [25-31]. As a result, SECM has been applied in various fields such as biology to study the respiratory chain of Escherichia coli [32] or in forensic sciences to image human fingerprints $[33,34]$.

As a preliminary step to protein quantification, protein structure elucidation is generally carried out in proteomic studies. In this context, as it may provide important information, selective tagging of proteins has been extensively studied by several techniques such as mass spectrometry $[35,36]$. One interesting approach is the tagging of free cysteines containing proteins and peptides by benzoquinone [37]. This reaction follows a classical 1,4-Michael addition mechanism with a high selectivity for cysteine groups in acidic $\mathrm{pHs}(\mathrm{pH}<4)$ and an extended reactivity for other nucleophilic groups (e.g. lysine and histidine) at a higher $\mathrm{pH}(\mathrm{pH}>4)$ [38-40]. Herein, we present a new SECM protein detection approach based on the tagging of proteins with benzoquinone and the further electrochemical detection of the quinone-protein adducts by the recycling of a redox mediator. The present methodology is simpler than metal staining and presents the advantage of being suitable for both general (i.e. tagging 
of cysteine, histidine and lysine) and selective (i.e. tagging of cysteine) protein detections. Additionally to provide relevant information for protein identification, a sensitivity in the low $\mathrm{ng} \mathrm{mm^{-2 }}$ range is afforded.

\section{Experimental methods}

\subsection{Chemicals}

$\mathrm{KNO}_{3}$ ( $\left.\geqslant 99 \%\right), \mathrm{KCl}(\geqslant 99.5 \%), \mathrm{CH}_{3} \mathrm{COOH}(>99.8 \%), \mathrm{CH}_{3} \mathrm{COONa}$ (>99\%), $\mathrm{Na}_{2} \mathrm{~S}_{2} \mathrm{O}_{3} \cdot 5 \mathrm{H}_{2} \mathrm{O}$ (>99.5\%), $\mathrm{Na}_{2} \mathrm{CO}_{3}$ (>99.5\%), $\mathrm{AgNO}_{3}(>99.5 \%)$ and ethanol $(>96 \%)$ were purchased from Fluka (Buchs, Switzerland). Methanol and $\mathrm{K}_{3}\left[\mathrm{Fe}(\mathrm{CN})_{6}\right](\geqslant 99 \%)$ were purchased from Merck (Dietikon, Switzerland). $\mathrm{K}_{3}\left[\mathrm{IrCl}_{6}\right]$ ( $\geqslant 99.5 \%$ ), bovine serum albumin (BSA) $(\geqslant 90 \%)$ and horse heart myoglobin (MYO) $(\geqslant 90 \%)$ were purchased from Sigma-Aldrich (Schnelldorf, Switzerland). All the chemicals were used as received. Deionized water was produced by a Milli-Q plus 185 model from Millipore (Zug, Switzerland). PVDF membranes for protein blotting were purchased from Bio-Rad (Hercules, CA, USA).

\subsection{Protein tagging and silver staining on PVDF membranes}

BSA or MYO $(1 \mu \mathrm{L})$ solution were deposited over a PVDF membrane with a microsyringe. Previously to the protein spotting, the

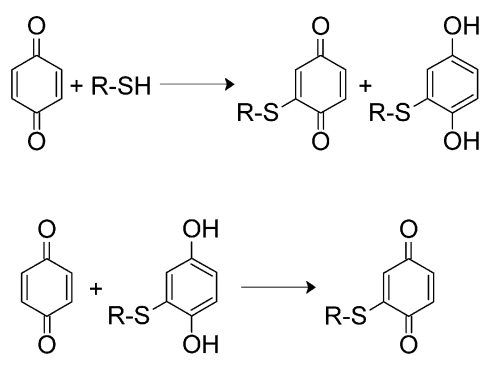

R-S = Free cysteine containing protein

Scheme 1. General reactions for the tagging of proteins with benzoquinone.
PVDF membrane was wetted in methanol and water. To avoid the formation of any significant topographical differences, the needle of the microsyringe was not in physical contact with the PVDF membrane during the deposition process. After sample application, PVDF membranes were dried under a gentle nitrogen flux. For subsequent tagging, the whole membrane was then submerged in an aqueous solution of acetic acid (0-44 $\mathrm{g} / \mathrm{L} \mathrm{AcOH})$ with benzoquinone $(0.2 \mathrm{mM}-200 \mathrm{mM})$ for various durations (1-12 h) with constant shaking. For the detection of the hydroquinone-protein adducts, a reduction step with a solution of $\mathrm{Sn}(\mathrm{II})\left(130 \mathrm{mM} \mathrm{SnCl}_{2}\right.$, $0.5 \mathrm{M} \mathrm{HCl}, 1.0 \mathrm{M} \mathrm{NaCl}$ ) was performed overnight. The procedure used for silver staining proteins on PVDF membranes has been introduced elsewhere [19,41]. The PVDF membrane was then washed extensively with water, dried, taped over a microscopic glass and finally scanned by SECM. Protein inked human fingerprints were prepared by microcontact printing $(\mu \mathrm{CP})$ as described elsewhere using the fingerprint of one volunteer [34].

\subsection{SECM measurements}

SECM measurements were carried out using a custom-built SECM setup running under SECMx software [42] and comprising an IVIUM compactstat (IVIUM Technologies, The Netherlands) operating in a classical three-electrode mode or under bipotentiostatic conditions. Data analyses were carried out using MIRA software [43]. The electrochemical cell comprises a silver wire as the quasi-reference electrode (Ag-QRE), a platinum wire as the counter electrode. As the working electrode, a Pt microelectrode (UME) with a radius equal to $11 \mu \mathrm{m}$ and a RG (radius of the insulating glass sheath over electrode radius (a)) between three and four if not specified in the figure captions. All potentials are reported with respect to the Ag-QRE. Pt microelectrodes were polished by a succession of diamond lapping discs (Ultra-prep, Buehler, Schlieren, Switzerland) with different particle sizes of $30 \mu \mathrm{m}, 6 \mu \mathrm{m}$, and $0.1 \mu \mathrm{m}$. After polishing, the quality and the RG of the electrodes was checked with a Laborlux D optical microscope (Leitz, Germany). All the samples were mounted on the bottom of a flat table used as sample holder for SECM experiments and SECM images were performed by placing the electrode at a constant height from the surface of the sample (constant height mode). All the measurements were performed at room temperature $\left(20 \pm 2{ }^{\circ} \mathrm{C}\right.$ ).

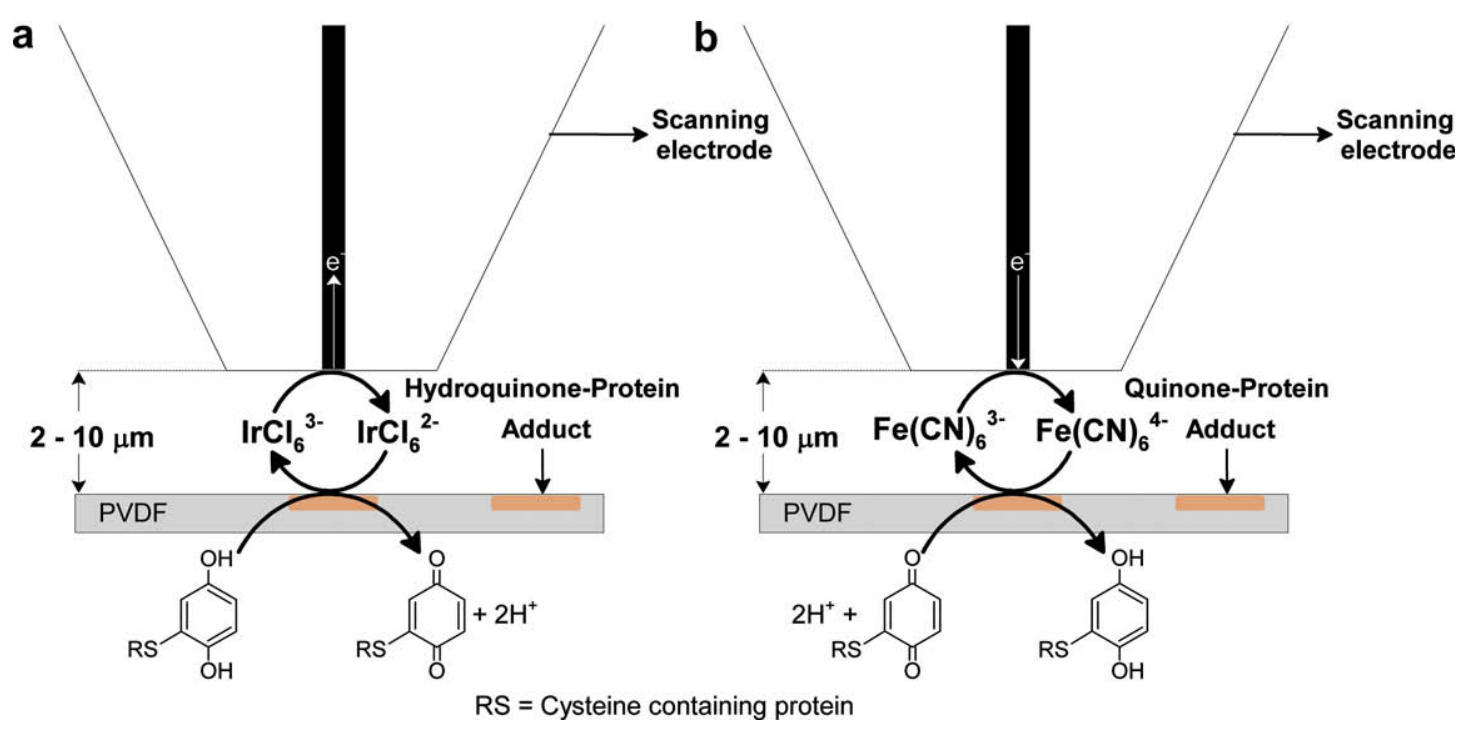

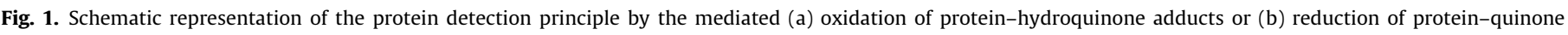
adducts. 


\section{Results and discussions}

\subsection{Protein tagging reaction and SECM detection principle}

The tagging of proteins with benzoquinone is based on a 1,4Michael reaction mechanism. The general reaction is depicted as reaction one in Scheme 1, where " $R$ " is the protein that contains free thiol groups "SH", which can react with benzoquinone to produce a mixture of benzoquinone and hydroquinone-protein adducts. The composition of the obtained products can be tuned by the amount of benzoquinone added at the beginning of the reaction (reaction two in Scheme 1). The protocol for the tagging reaction is simpler than other protein labeling techniques, since it is a one-step procedure where it is only required to wet the PVDF membrane with an acidic or neutral solution of benzoquinone for a given duration (1-3 h). In addition, since this is an endpoint protocol, the membrane can be left in the benzoquinone solution for prolonged periods of time without over staining. This is an important advantage over previous silver staining techniques in which the staining intensity may significantly vary from experiment to experiment and high background signals can be easily obtained.

Depending on the type of protein adduct produced in the tagging reaction, a different strategy for the electrochemical protein detection is proposed. Indeed, either the hydroquinone-protein adducts (Fig. 1a) or the quinone-protein adducts (Fig. 1b) can be targeted. The first strategy requires a prior reduction of the quinone-protein adducts before the SECM scanning, to reach a maximum detected quantity of hydroquinone-protein adducts. With this aim, the tagged protein spots were first reduced overnight with a $\mathrm{Sn}$ (II) solution (130 mM SnCl $2,0.5 \mathrm{M} \mathrm{HCl}, 1.0 \mathrm{M} \mathrm{NaCl}$ ). Then, the PVDF membrane was washed extensively with water and imaged by SECM. The tagged and further reduced protein spots were then detected by using $\mathrm{IrCl}_{6}^{3-}$ as the redox mediator (see Supporting Information S1). Although a protein spot of $50 \mathrm{ng} \mathrm{mm}^{-2}$ of BSA was observed, this option was not further selected since hydroquinone species can be easily re-oxidized in presence of oxygen. As a consequence, the current intensity over the protein spots decreases drastically after the first scan. Before to analyze or reanalyze these samples, an additional reduction step would have to be performed in order to keep the signal intensity. This problem has been recently solved for the detection of DNA hybridization, where DNA strands were deposited over a quinone polymer matrix supported on a carbon fiber electrode and the hydroquinone species were in situ produced at the negatively biased electrode [44]. A high amount of hydroquinone groups were thus available to undergo a reaction with the redox mediator $\left(\mathrm{Fe}(\mathrm{CN})_{6}^{3-}\right)$ generated at the SECM tip. Herein, as the supporting PVDF membrane is an insulating material, this previously reported approach cannot be applied.

To circumvent these problems, a second strategy (Fig. 1b) was explored where the recycling of the redox mediator $\left(\mathrm{Fe}(\mathrm{CN})_{6}^{4-}\right)$ is associated to the reduction of benzoquinone-protein adducts, which can be the main product if an excess of benzoquinone is employed during the tagging reaction (reaction two in Scheme 1). In comparison with the first approach, the current intensity over the protein spots remains stable after several scans (see Supporting Information S2).

\subsection{Optimization of the tagging reaction}

Two parameters have firstly been considered for optimizing the tagging reaction. With this aim, several protein spots of similar concentration (500 $\mathrm{ng} \mathrm{mm}^{-2}$ of BSA) were tagged during different durations (1-12 h) and with various benzoquinone concentrations $(0.2-200 \mathrm{mM})$ in water without acetic acid. To be able to deter- mine the best conditions, all the protein spots were scanned by SECM under similar experimental conditions (e.g. probe-substrate distance, redox mediator concentration, microelectrode, microelectrode RG, translation speed and translation step). The current value was then monitored over each protein spot and the results compared as a function of the varying parameters. For being able to determine the best conditions, the current difference $\left(\Delta i_{\mathrm{T}}\right)$ obtained by subtracting the averaged background current from the
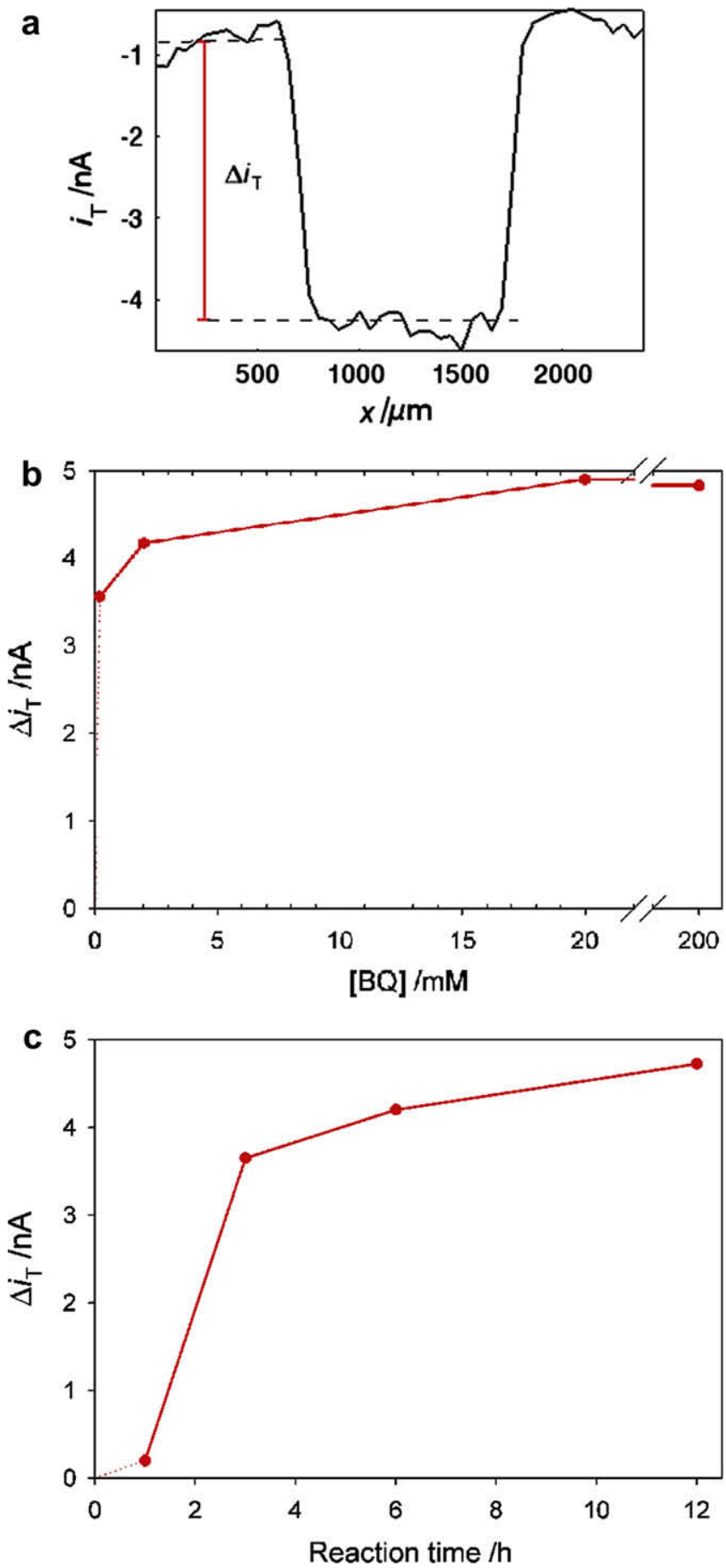

Fig. 2. (a) SECM line scan of a Pt UME ( $a=11 \mu \mathrm{m}, \mathrm{RG}=2-3$ ) over a protein spot tagged with Benzoquinone. (b) Benzoquinone concentration ([BQ]) and (c) reaction time optimization. $\Delta i_{\mathrm{T}}$ represents the current difference between the protein region and the background (noise). For all the experiments a $500 \mathrm{ng}$ protein spot of BSA over PVDF was prepared. Imaging conditions: $2.0 \mathrm{mM} \mathrm{K}_{3}\left[\mathrm{Fe}(\mathrm{CN})_{6}\right]$ in $0.1 \mathrm{M} \mathrm{KNO}_{3}$, translation speed $50 \mu \mathrm{m} \mathrm{s}^{-1}$, step $50 \mu \mathrm{m}, d=4 \mu \mathrm{m}$ and $E_{\mathrm{T}}=-0.2 \mathrm{~V}$. 
averaged current recorded over the protein spot (Fig. 2a) was taken into account. This current difference was plotted as a function of the different tested conditions (Fig. $2 \mathrm{~b}$ and c). For the benzoquinone concentration, it can be seen that $20 \mathrm{mM}$ benzoquinone concentration is appropriate for the tagging reaction, since no further increment on the current difference is observed at higher concentrations (Fig. 2b). Additionally, higher concentrations of benzoquinone are hardly obtained due to the limited benzoquinone solubility in water. A benzoquinone excess was employed for the tagging reaction as it not only tags the cysteine groups but also other nucleophilic aminoacids (vide infra). Also, benzoquinone acts as an oxidative agent for hydroquinone-protein adducts (reaction two in Scheme 1). Then considering Fig. 2c, $3 \mathrm{~h}$ was subsequently chosen as the optimum reaction time as it provides a good compromise between signal intensity and experiment duration. Previous studies performed in solution showed that a tagging reaction yield of almost $100 \%$ was achieved in $1 \mathrm{~h}$ [40]. The longer experimental time required in the present methodology is certainly a consequence of the heterogeneous nature of the reaction occurring between benzoquinone and adsorbed proteins. As the reactive species in this Michael type reaction is mainly the thiolate $\left(-S^{-}\right)$, the reaction rate can also be affected by the $\mathrm{pH}$ of the solution. Other experimental parameters such as the charge of the neighboring groups and the steric hindrance induced by the protein structure may also lower the availability of free cysteine groups $[39,45,46]$. In this work, the solution $\mathrm{pH}$ was 6.4 , which provides an appreciable amount of thiolate groups without affecting the benzoquinone stability. As reported in other studies, if further required, the rate of the tagging reaction may also be enhanced by using benzoquinone derivates with electron withdrawing groups, like the carboxymethyl [47].

\subsection{Sensitivity and selectivity}

The sensitivity of the present technique was assessed by spotting different protein quantities with concentrations ranging from 0.5 to $500 \mathrm{ng} \mathrm{mm}^{-2}$ on a PVDF membrane. The protein tagging was then performed under the previously optimized conditions. As demonstrated by the Fig. 3a, the protein spots corresponding to protein amounts of $500 \mathrm{ng}, 50 \mathrm{ng}$ and even $5 \mathrm{ng}$ can be detected by using the proposed detection technique. The spot containing $0.5 \mathrm{ng}$ of BSA could not be observed. From Fig. 3 and the SECM imaging of a similar sample (result not shown), eight line scans were extracted by using MIRA software (four line scans from each image) in order to establish for each protein spot the current difference $\left(\Delta i_{\mathrm{T}}\right)$. Average values of these differences were then plotted
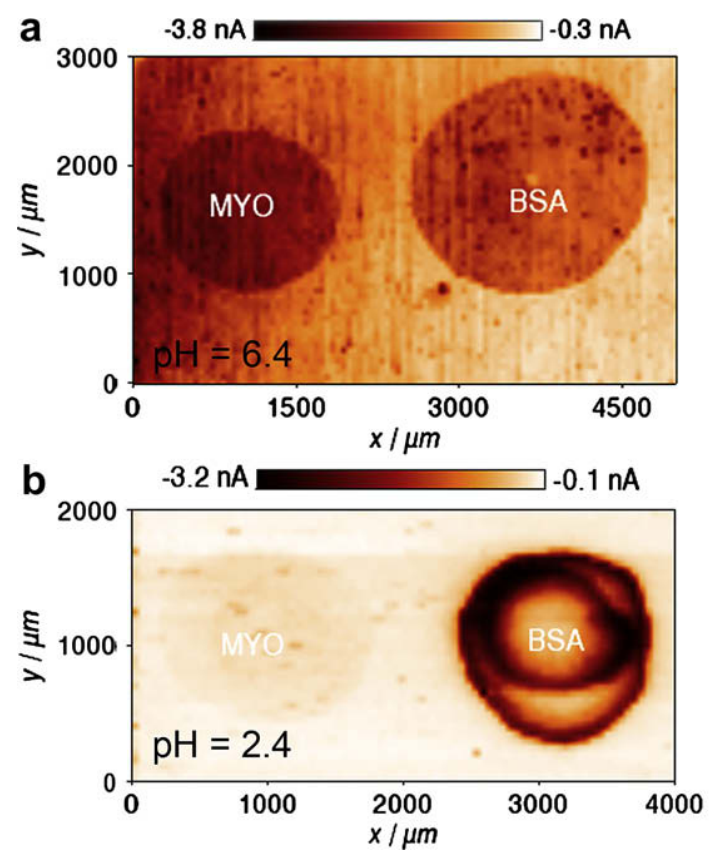

Fig. 4. Constant height images of tagged BSA (500 ng) and MYO (500 ng) protein spots over PVDF membrane in an aqueous solution of $2.2 \mathrm{mM} \mathrm{K}_{3}\left[\mathrm{Fe}(\mathrm{CN})_{6}\right]$ in $\mathrm{KNO}_{3}$ $0.1 \mathrm{M}$. Tagging reaction conditions: (a) $\mathrm{pH}=2.44$ and (b) $\mathrm{pH}=6.4$ (the $\mathrm{pH}$ was adjusted with acetic acid), benzoquinone $=20 \mathrm{mM}$ and reaction time $=3 \mathrm{~h}$. Imaging conditions: translation speed $50 \mu \mathrm{m} \mathrm{s}^{-1}$, step $50 \mu \mathrm{m}, d=4 \mu \mathrm{m}$ and $E_{\mathrm{T}}=-0.2 \mathrm{~V}$.

against the BSA surface concentration. The results are showed in Fig. $3 \mathrm{~b}$, where the error bars correspond to the standard deviation of the calculated current differences. Despite the minimum protein surface concentration observable with this method is $5 \mathrm{ng} \mathrm{mm}^{-2}$, the statistical value of the limit of detection is undoubtedly higher as the observed background noise is rather strong (signal to noise ratio of 1.6 for $5 \mathrm{ng} \mathrm{mm}^{-2}$ ). Still, in addition to the proof of concept of the methodology, it can be assessed that the developed method allows for a limit of detection in the low $\mathrm{ng} \mathrm{mm^{-2 }}$ range, which is of the same magnitude as those provided by the state of the art protein detection over PVDF membranes [13,48,49].

However the current difference increases with the protein concentration, further experiments will have to be performed to thoroughly characterize the proposed method by for example determining its limit of quantification and linear dynamic range. Therefore more protein concentration points will have to be
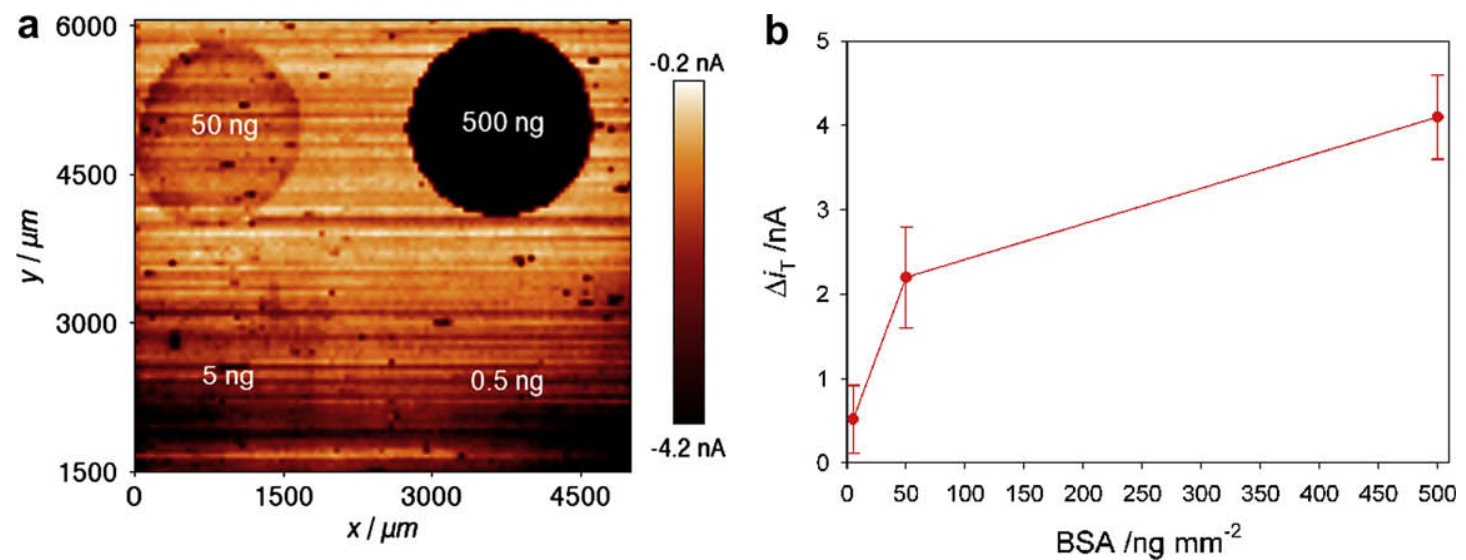

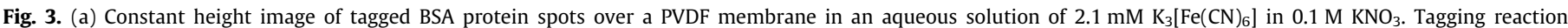

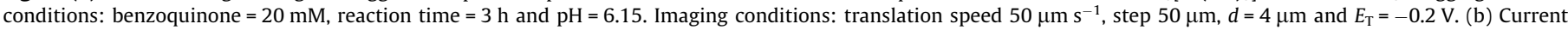
difference between the protein region and the background $\left(\Delta i_{\mathrm{T}}\right)$ as a function of the BSA concentration. 
considered and a special attention to the generated background noise will have to be given.

As compared to other techniques, the developed approach presents the advantage of being suitable for both general or cysteine selective protein detections, since the selectivity of the tagging reaction can be tuned simply by changing the $\mathrm{pH}$ of the reaction. Under rather strong acidic conditions $(\mathrm{pH}<4)$, only free cysteine groups are tagged while a more universal detection is provided when the tagging reaction is carried out under weakly acidic conditions, where benzoquinone also reacts with other nucleophiles (e.g. lysine and histidine). To demonstrate this capability, BSA and MYO were employed as test proteins. BSA contains 35 cysteine groups, but only one free cysteine is available for the tagging reaction and MYO does not contain any cysteine amino-acid residues inside its structure. The results shown in Fig. 4 confirm this capability. Thereby, relevant information for protein identification and sensitive protein quantification may be obtained in parallel. The low background current observed over the protein spot of MYO at pH 2.44 is more likely originating from the electrochemical activity of the iron contained in the protein rather than from a par- tial tagging. These results are in good agreement with the results obtained by performing the same reaction at different pH's and studying the reaction products by mass spectrometry [40]. As far as we know, there is no other protein detection method that can be employed for both general and cysteine selective protein detections.

\subsection{SECM imaging of human fingerprint}

Just as silver staining [34], this new protein detection method can be employed in conjunction with SECM for various applications. As an example, its application to the imaging of human fingerprints is reported herein. After having obtained a human fingerprint by a previously described protocol [34], the sample was cut into two pieces, one being submitted to silver staining and the other one to benzoquinone tagging. Afterwards, a portion of each piece was imaged by SECM using either hexachloroiridiate or ferrocyanide as redox mediator (Fig. 5). From the two images, it is possible to identify several factors relevant for the verification of a human identity (i.e. the position of the ridges and their deviations
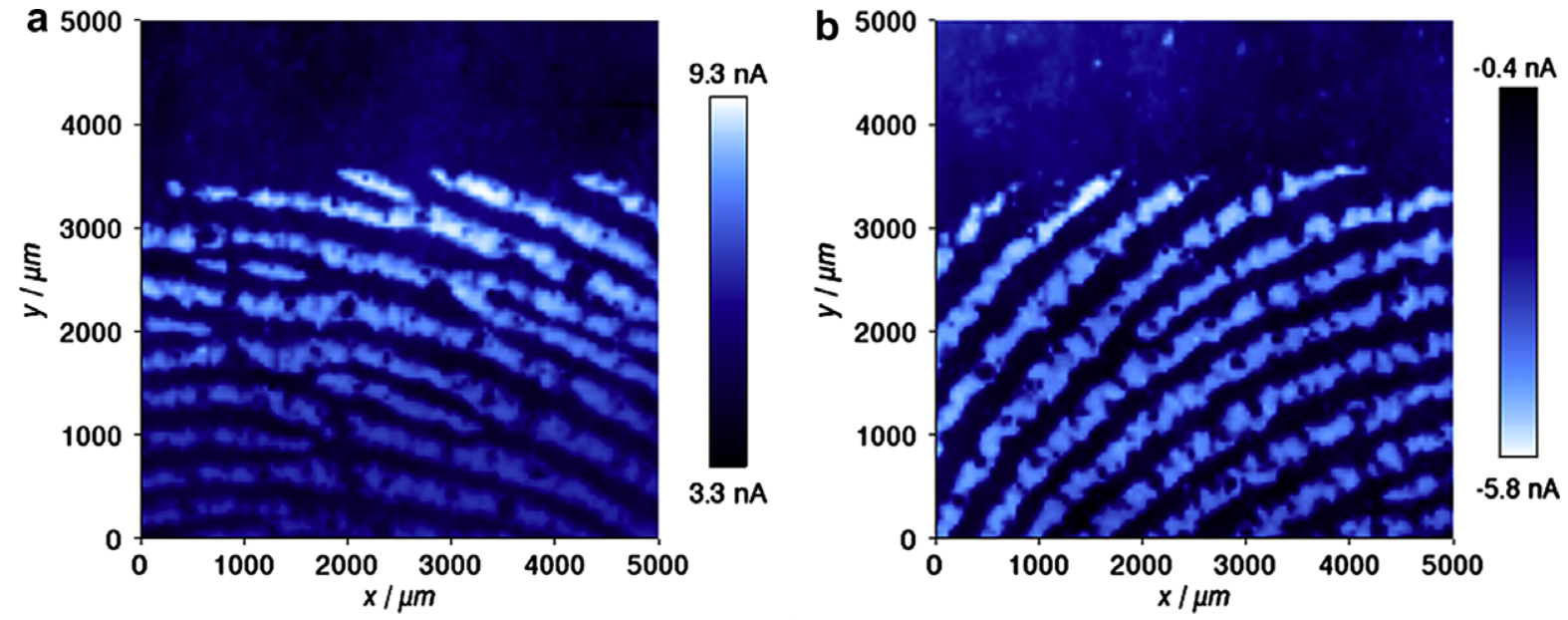

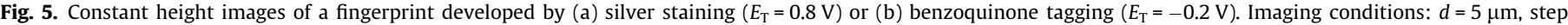

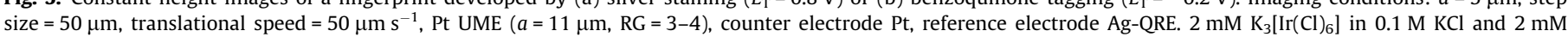
$\mathrm{K}_{3}\left[\mathrm{Fe}(\mathrm{CN})_{6}\right]$ in $0.1 \mathrm{M} \mathrm{KNO}_{3}$ were used as redox mediators for figure (a) and (b), respectively.
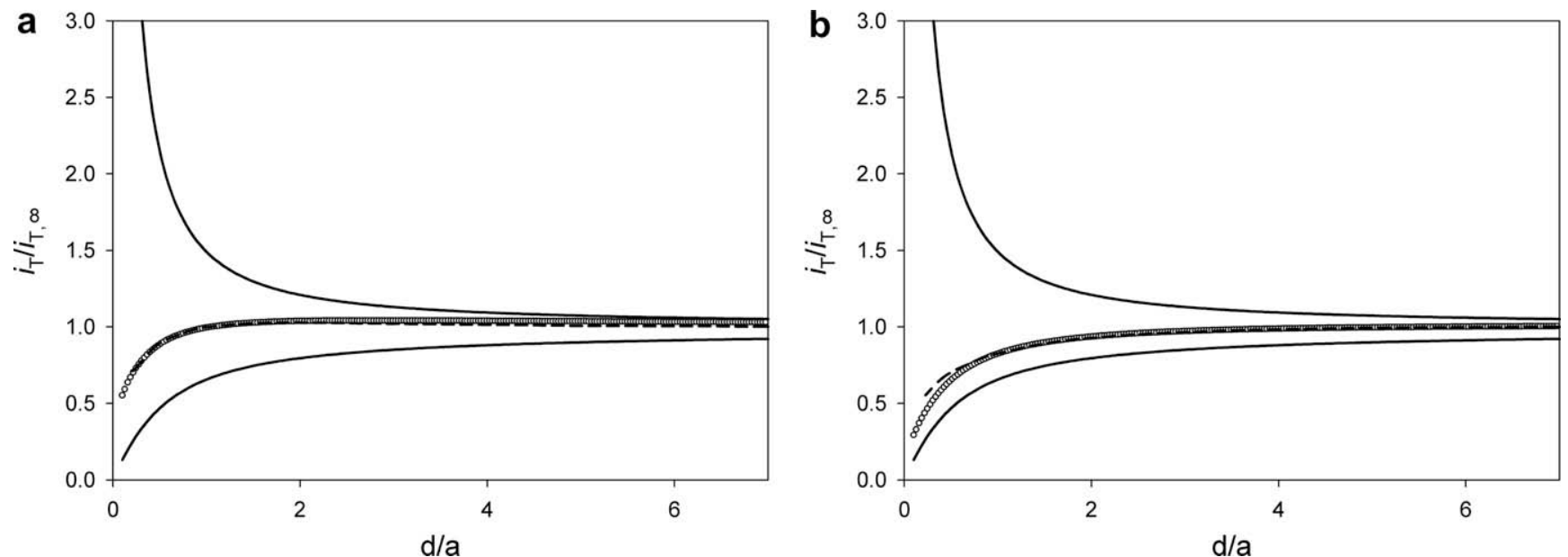

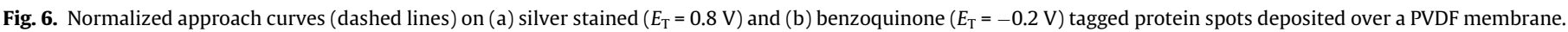

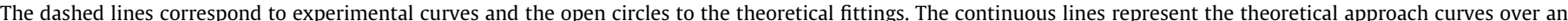

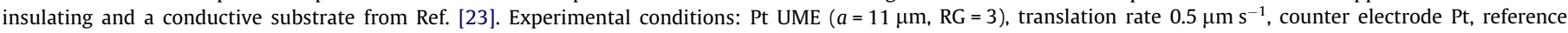
electrode Ag-QRE. $2.4 \mathrm{mM} \mathrm{K}_{3}\left[\operatorname{Ir}(\mathrm{Cl})_{6}\right]$ in $0.1 \mathrm{M} \mathrm{KCl}$ and $2.2 \mathrm{mM} \mathrm{K} 3\left[\mathrm{Fe}(\mathrm{CN})_{6}\right]$ in $0.1 \mathrm{M} \mathrm{KNO}_{3}$ were used as redox mediators for figure (a) and (b), respectively. 
as well as the shape and relative position of the pores of each part of a ridge). Considering the Fig. 5, it appears that the new methodology reveals the same level of information than the actual SECM state-of-the-art for fingerprint imaging. According to a previous report [19], silver staining provides a higher sensitivity due to both a higher number of active species per protein molecule and a higher apparent heterogeneous kinetic constant. This is confirmed by comparing approach curves performed either over a benzoquinone tagged or silver stained protein spot ( $2 \mu \mathrm{g}$ of BSA) with the model proposed by Cornut and Lefrou [23] (Fig. 6). The values of the apparent heterogeneous kinetic constant $(k)$ for the reduction of the benzoquinone-protein adducts and the dissolution of silver nanoparticles were determined to be equal to $8.0 \times 10^{-4} \mathrm{~cm} \mathrm{~s}^{-1}$ and $2.5 \times 10^{-3} \mathrm{~cm} \mathrm{~s}^{-1}$, respectively.

\section{Conclusions}

A new approach for protein detection on PVDF membranes has been developed taking advantage of the reaction occurring between benzoquinone, proteins and peptides. By using a scanning microelectrode and the recycling of a redox mediator $\left(\mathrm{Fe}(\mathrm{CN})_{6}^{3-}\right)$, the spatial localization of tagged protein spots can be determined. Depending on the requirements, cysteine selective or universal protein detections can be achieved by simply tuning the $\mathrm{pH}$ during the tagging reaction. Under rather strong acidic conditions, only free cysteines are available for tagging while other aminoacids such as lysine and histidine react at a higher $\mathrm{pH}$. These results demonstrate the feasibility of using SECM to detect benzoquinone tagged proteins when immobilized on a porous membrane surface. Besides being potentially suitable for protein quantification, the proposed detection method should also be suitable for studying the transduction of an oxidant signal into a biological response and the elucidation of available cysteines groups within natural or engineered proteins. It has also to be noticed that the reported detection technique is fully compatible with mass spectroscopy. As such, it might be considered as an interesting preliminary step to improve the confidence of the identification process. In order to thoroughly characterize the proposed methodology, future work will include the optimization of parameters such as, the tag molecule, the redox mediator, protein spots application procedure and the minimization of the background signal originating from the PVDF membrane topography.

\section{Acknowledgements}

The Fonds National Suisse pour la Recherche Scientifique(Grant No. 20PA21_121570/1 "High throughput SECM imaging") is thanked for the financial support. We are grateful to Michel Prudent, Manuel Alejandro Mendez, Christophe Roussel, Loic Dayon and Melanie Abonnenc for their helpful discussions. The technical assistance by Valérie Devaud is also acknowledged. Finally, Prof. G. Wittstock is thanked for its technical support in the assembly and update of the SECM setup.

\section{Appendix A. Supplementary material}

Supplementary data associated with this article can be found, in the online version, at doi:10.1016/j.jelechem.2009.08.007.

\section{References}

[1] W.F. Patton, J. Chromatogr. B 771 (2002) 3-31.

[2] S. Sriyam, S. Sinchaikul, P. Tantipaiboonwong, C. Tzao, S. Phutrakul, S.T. Chen, J. Chromatogr. B 849 (2007) 91-104.

[3] S.K. Pedersen, J.L. Harry, L. Sebastian, J. Baker, M.D. Traini, J.T. McCarthy, A. Manoharan, M.R. Wilkins, A.A. Gooley, P.G. Righetti, N.H. Packer, K.L. Williams, B.R. Herbert, J. Proteome. Res. 2 (2003) 303-311.

[4] P.G. Righetti, A. Castagna, B. Herbert, G. Candiano, Biosci. Rep. 25 (2005) 3-17.

[5] T. Rabilloud, L. Vuillard, C. Gilly, J.J. Lawrence, Cell. Mol. Biol. 40 (1994) 57-75.

[6] V. Neuhoff, N. Arold, D. Taube, W. Ehrhardt, Electrophoresis 9 (1988) 255-262.

[7] T.H. Steinberg, B.J. Agnew, K.R. Gee, W.Y. Leung, T. Goodman, B. Schulenberg, J. Hendrickson, J.M. Beechem, R.P. Haugland, W.F. Patton, Proteomics 3 (2003) 1128-1144.

[8] C.R. Merril, Methods Enzymol. 182 (1990) 477-488.

[9] A. Mayer, S. Neuenhofer, Angew. Chem. Int. Ed. 33 (1994) 1044-1072.

[10] D.S. Wilbur, Bioconjug. Chem. 3 (1992) 433-470.

[11] H. Zhang, E.S. Yeung, Electrophoresis 27 (2006) 3609-3618.

[12] K. Berggren, T.H. Steinberg, W.M. Lauber, J.A. Carroll, M.F. Lopez, E. Chernokalskaya, L. Zieske, Z. Diwu, R.P. Haugland, W.F. Patton, Anal. Biochem. 276 (1999) 129-143.

[13] R. Westermeier, R. Marouga, Biosci. Rep. 25 (2005) 19-32.

[14] G. Wittstock, Anal. Bioanal. Chem. 370 (2001) 303-315.

[15] G. Wittstock, K.J. Yu, H.B. Halsall, T.H. Ridgway, W.R. Heineman, Anal. Chem. 67 (1995) 3578-3582.

[16] M. Carano, N. Lion, J.P. Abid, H.H. Girault, Electrochem. Commun. 6 (2004) 1217-1221.

[17] M. Carano, N. Lion, H.H. Girault, Chimia 59 (2005) 105-108.

[18] M. Carano, N. Lion, H.H. Girault, J. Electroanal. Chem. 599 (2007) 349-355.

[19] M. Zhang, G. Wittstock, Y. Shao, H.H. Girault, Anal. Chem. 79 (2007) 48334839.

[20] A.J. Bard, M.V. Mirkin (Eds.), Scanning electrochemical microscopy. John Wiley and sons, New York, 2001.

[21] J. Kwak, A.J. Bard, Anal. Chem. 61 (1989) 1221-1227.

[22] C. Wei, A.J. Bard, M.V. Mirkin, J. Phys. Chem. 99 (1995) 16033-16042.

[23] R. Cornut, C. Lefrou, J. Electroanal. Chem. 621 (2008) 178-184.

[24] M.A. Edwards, S. Martin, A.L. Whitworth, J.V. Macpherson, P.R. Unwin, Physiol. Meas. 27 (2006) (art. no. R01).

[25] Y. Selzer, I. Turyan, D. Mandler, J. Phys. Chem. B 103 (1999) 1509-1517.

[26] A.J. Bard, M.V. Mirkin, P.R. Unwin, D.O. Wipf, J. Phys. Chem. 96 (1992) 18611868.

[27] A.L. Barker, M. Gonsalves, J.V. MacPherson, C.J. Slevin, P.R. Unwin, Anal. Chim. Acta 385 (1999) 223-240.

[28] P. Sun, M.V. Mirkin, Anal. Chem. 78 (2006) 6526-6534.

[29] B. Liu, A.J. Bard, M.V. Mirkin, S.E. Creager, J. Am. Chem. Soc. 126 (2004) 14851492.

[30] D. Mandler, P.R. Unwin, J. Phys. Chem. B 107 (2003) 407-410.

[31] X. Lu, Q. Wang, X. Liu, Anal. Chim. Acta 601 (2007) 10-25.

[32] K.B. Holt, A.J. Bard, Biochemistry 44 (2005) 13214-13223.

[33] M. Zhang, A. Becue, M. Prudent, C. Champod, H.H. Girault, Chem. Commun. (2007) 3948-3950.

[34] M. Zhang, H.H. Girault, Electrochem. Commun. 9 (2007) 1778-1782.

[35] S. Wang, X. Zhang, F.E. Regnier, J. Chromatogr. A 949 (2002) 153-162.

[36] S. Sechi, B.T. Chait, Anal. Chem. 70 (1998) 5150-5158.

[37] T.C. Rohner, J.S. Rossier, H.H. Girault, Electrochem. Commun. 4 (2002) 695700.

[38] C. Roussel, L. Dayon, N. Lion, T.C. Rohner, J. Josserand, J.S. Rossier, H. Jensen, H.H. Girault, J. Am. Soc. Mass. Spectrom. 15 (2004) 1767-1779.

[39] C. Roussel, T.C. Rohner, H. Jensen, H.H. Girault, Chem. Phys. Chem. 4 (2003) 200-206.

[40] L. Dayon, Ecole Polytechnique Federale de Lausanne (EPFL), Lausanne, 2006.

[41] B.K. Sørensen, P. Højrup, E. Østergård, C.S. Jørgensen, J. Enghild, L.R. Ryder, G. Houen, Anal. Biochem. 304 (2002) 33-41.

[42] K.C. Nunes, K.H. Hallmeier, R. Szargan, T. Raschke, C. Radehaus, G. Wittstock, Electroanalysis 19 (2007) 1023-1031.

[43] G. Wittstock, T. Asmus, T. Wilhelm, Fresenius' J. Anal. Chem. 367 (2000) 346351.

[44] K. Nakano, K. Nakamura, K. Iwamoto, N. Soh, T. Imato, J. Electroanal. Chem. 628 (2009) 113-118.

[45] L. Dayon, C. Roussel, H.H. Girault, J. Proteome. Res. 5 (2006) 793-800.

[46] M.P. Lutolf, N. Tirelli, S. Cerritelli, L. Cavalli, J.A. Hubbell, Bioconjug. Chem. 12 (2001) 1051-1056.

[47] C. Roussel, L. Dayon, H. Jensen, H.H. Girault, J. Electroanal. Chem. 570 (2004) 187-199.

[48] S. Harper, D.W. Speicher, in: J.E. Coligan (Ed.), Current Protocols in Protein Science, John Wiley \& Sons, Inc., 2001 (Chapter 10).

[49] J. Sasse, S.R. Gallagher, in: J.E. Coligan (Ed.), Current Protocols in Immunology, John Wiley \& Sons, Inc., 2008 (Suppl. 83). 